\title{
PENGARUH AKREDITASI PRODI, MOTIVASI, FASILITAS PENDIDIKAN \\ DAN REPUTASI PENDIDIK TERHADAP KEPUTUSAN MAHASISWA DALAM MEMILIH PROGRAM STUDI SARJANA TERAPAN AKUNTANSI SEKTOR PUBLIK PADA POLITEKNIK HARAPAN BERSAMA TEGAL \\ (Studi Empiris Pada Mahasiswa Program Studi Sarjana Terapan Akuntansi Sektor Publik di Politeknik Harapan Bersama )
}

\author{
Nurul Mahmudah \\ Nurulmahmudah1989@gmail.com \\ Yusri Anis Faidah \\ yusrianis@ymail.com \\ Program Studi Sarjana Terapan Akuntansi Sektor Publik \\ Politeknik Harapan Bersama
}

\begin{abstract}
This study aims to analyze the effect of department's accreditation, motivation, educational facilities and educators' reputation on student decisions in choosing the applied bachelor of public sector accounting department in polytechnic Harapan Bersama in Tegal (empirical studies on students applying applied bachelor of public sector accounting department in the polytechnic Harapan Bersama). This study is a quantitative study with data collection techniques were based on the results of the questionnaire. The population in this study amounted to 47 students, which was taken by using purposive sampling. The sampling criteria are students who applied and registered to became active students in the applied bachelor of public sector accounting department in the 2019-2020 academic year. So that the sample in this study was 44 students. The data analysis method in this study used multiple regression analyzed by SPSS software. The results showed that the variables of the department's accreditation, motivation, and educational facilities did not influence the decision to choose the applied bachelor of public sector accounting department, however for the reputation variable; the educator partially affected the decision to choose the applied bachelor of public sector accounting department. While the accreditation of department, motivation and educational facilities and the reputation of educators simultaneously influenced the decision to choose the applied bachelor of public sector accounting department.
\end{abstract}

Keywords: accreditation, motivation, educational facilities, educator reputation, decision to choose.

\begin{abstract}
ABSTRAK
Penelitian ini bertujuan untuk menganalisis pengaruh akreditasi prodi, motivasi, fasilitas pendidikan dan reputasi pendidik terhadap keputusan mahasiswa dalam memilih program studi sarjana terapan akuntansi sektor publik pada politeknik harapan bersama tegal (studi empiris pada mahasiswa program studi sarjana terapan akuntansi sektor publik di politeknik Harapan Bersama). Penelitian ini merupakan penelitian kuantitatif dengan teknik pengumpulan data berdasarkan hasil kuesioner. Populasi dalam penelitian ini berjumlah 47 mahasiswa, sampel dalam penelitian ini menggunakan purposive sampling. dengan kriteria pengambilan sampel adalah Mahasiswa yang mendaftar dan registrasi serta mahasiswa aktif yang ada di program studi sarjana terapan akuntansi sektor publik tahun akademik 2019/2020. Sehingga sampel dalam penelitian ini sejumlah 44 mahasiswa. Metode analisis data dalam penelitian ini menggunakan regresi berganda dengan menggunakan software SPSS. Hasil penelitian menunjukan bahwa secara parsial untuk variabel akreditasi program studi, motivasi dan fasilitas pendidikan tidak berpengaruh terhadap keputusan memilih program studi sarjana terapan akuntansi sektor publik, untuk variabel reputasi pendidik secara parsial berpengaruh terhadap keputusan memilih program studi sarjana terapan akuntansi sektor publik. Sedangkan secara simultan akreditasi program studi, motivasi dan fasilitas pendidikan dan reputasi pendidik berpengaruh terhadap keputusan memilih program studi sarjana terapan akuntansi sektor publik.
\end{abstract}

Kata kunci: akreditasi, motivasi, fasilitas pendidikan, reputasi pendidik, keputusan memilih. 


\section{PENDAHULUAN \\ Latar Belakang}

Pendidikan mempunyai peranan yang sangat penting dalam meningkatkan kualitas sumber daya manusia. Subandowo (dalam Aini, 2010) menyatakan pendidikan merupakan salah satu faktor yang sangat fundamental dalam upaya meningkatkan kualitas kehidupan. Pendidikan dipandang sebagai sarana yang paling strategis untuk mengangkat harkat dan martabat suatu bangsa. Lulusan siswa SMA/SMK sederajat menjadi peluang bagi seluruh perguruan tinggi yang ada di Kota Tegal. Siswa-siswi dapat melanjutkan studinya ke jenjang pendidikan yang lebih tinggi, baik pada Perguruan Tinggi Negeri (PTN), maupun Perguruan Tinggi Swasta (PTS), dalam hal ini baik itu PTN maupun PTS memiliki peluang yang sama untuk dipilih oleh calon mahasiswa.

Politeknik Harapan Bersama merupakan salah satu perguruan tinggi swasta yang ada di kota Tegal. Politeknik Harapan Bersama memiliki Tujuh Program Studi diantaranya Program Studi D3 Teknik Elektro, Program Studi D3 Teknik Mesin, Program Studi D3 Teknik Komputer, Program Studi D3 Akuntansi, Program Studi D3 Kebidanan, Program Studi D3 Farmasi, Program Studi Sarjana Terapan Teknik Informatika. Saat ini Politeknik Harapan Bersama telah berkembang pesat ditahun 2020 sudah memiliki sepuluh Program Studi diantaranya, Sarjana Terapan Akuntansi Sektor Publik, Program Studi Sarja Terapan Teknik Informatika, Program Studi D3 Teknik Elektro, Program Studi D3 Teknik Mesin, Program Studi D3 Teknik Komputer, Program Studi D3 Akuntansi, Program Studi D3 Kebidanan, Program Studi D3 Farmasi, Program Studi D3 Perhotelan, Program Studi D3 DKV (Desain Komunikasi Visual). Program Studi Sarjana Terapan Akuntansi Sektor Publik merupakan salahsatu program studi unggulan yang ada di politeknik harapan bersama dimana program studi ini berfokus pada Lulusan yang nantinya dapat menjadi akuntan publik, analis sistem informasi akuntansi publik dan analis perpajakan pada berbagai organisasi baik di sektor publik yang meliputi instansi pemerintah (pusat/daerah), BUMN/BUMD, Organisasi Nirlaba maupun di sektor privat.

Program Studi Sarjana Terapan Akuntansi Sektor Publik baru dibuka pada tahun akademik 2020-2020 dimana untuk program studi unggulan akuntansi sektor publik memiliki banyak peluang untuk tahun yang akan datang, hal ini di buktikan bahwa untuk program studi akuntansi sektor publik merupakan program studi satu-satunya yang ada di Jawa Tengah.

Adapun beberapa jurusan yang sejalan berada di Politeknik Negeri Jember, Politeknik Sriwijaya, Politeknik Negeri Kupang dan Universitas Terbuka (S1 Akuntansi Keuangan Pemerintah). Terlepas dari jurusan yang sejalan diatas bahwa persaingan terkait program studi yang sejalan pasti ada, khususnya didaerah jawa tengah.

Menurut Bawantara (2007) menyatakan bahwa hal-hal yang menjadi pertimbangan mahasiswa dalam melanjutkan kuliah di sebuah perguruan tinggi yaitu pendapatan keluarga, kelompok acuan, kemauan sendiri, dan keluarga. Menurut Amaliya' (2018) Hasil penelitian menunjukkan bahwa: Biaya pendidikan tidak berpengaruh terhadap keputusan mahasiswa, Citra prodi berpengaruh positif dan parsial terhadap keputusan, Fasilitas pendidikan berpengaruh positif dan parsial terhadap keputusan mahasiswa, Prospek prodi berpengaruh positif dan parsial terhadap keputusan mahasiswa. Menurut Verawati (2016) Berdasarkan hasil analisis data dapat disimpulkan bahwa faktorfaktor yang mempengaruhi minat mahasiswa untuk melanjutkan Magister Akuntansi meliputi motivasi, akreditasi program studi, fasilitas pendidika, konsentrasi jurusan, biaya pendidikan, dan reputasi pendidik. Sehingga dapat diartikan bahwa keenam variabel independen tersebut berpengaruh parsial terhadap minat mahasiswa untuk melanjutkan Magister Akuntansi

Berdasarkan paparan latar belakang di atas, maka dipandang perlu melakukan penelitian yang dituangkan dalam judul pengaruh akreditasi prodi, motivasi, fasilitas pendidikan dan reputasi pendidik terhadap keputusan mahasiswa dalam memilih program studi sarjana terapan akuntansi sektor publik pada politeknik harapan bersama tegal (Studi Empiris Pada Mahasiswa Program Studi Sarjana Terapan Akuntansi Sektor Publik di Politeknik Harapan Bersama Tegal)

\section{Permasalahan}

Berdasarkan uraian latar belakang di atas, maka rumusan masalah pada penelitian ini adalah: 
1. Apakah akreditasi prodi berpengaruh secara parsial terhadap keputusan mahasiswa dalam memilih program studi sarjana terapan akuntansi sektor publik pada Politeknik Harapan Bersama Tegal.

2. Apakah Motivasi berpengaruh secara parsial terhadap keputusan mahasiswa dalam memilih program studi sarjana terapan akuntansi sektor publik pada Politeknik Harapan Bersama Tegal.

3. Apakah fasilitas pendidikan berpengaruh secara parsial terhadap keputusan mahasiswa dalam memilih program studi sarjana terapan akuntansi sektor publik pada Politeknik Harapan Bersama Tegal.

4. Apakah reputasi pendidik berpengaruh secara parsial terhadap keputusan mahasiswa dalam memilih program studi sarjana terapan akuntansi sektor publik pada Politeknik Harapan Bersama Tegal.

5. Apakah akreditasi prodi, motivasi, fasilitas pendidikan dan reputasi pendidik berpengaruh secara simultan terhadap keputusan mahasiswa dalam memilih program studi sarjana terapan akuntansi sektor publik pada Politeknik Harapan Bersama Tegal.

\section{Tujuan}

Tujuan penelitian ini yaitu untuk:

1. Untuk mengetahui apakah akreditasi prodi berpengaruh secara parsial terhadap keputusan mahasiswa dalam memilih program studi sarjana terapan akuntansi sektor publik pada Politeknik Harapan Bersama Tegal.

2. Untuk mengetahui apakah motivasi berpengaruh secara parsial terhadap keputusan mahasiswa dalam memilih program studi sarjana terapan akuntansi sektor publik pada Politeknik Harapan Bersama Tegal.

3. Untuk mengetahui apakah fasilitas pendidikan berpengaruh secara parsial terhadap keputusan mahasiswa dalam memilih program studi sarjana terapan akuntansi sektor publik pada Politeknik Harapan Bersama Tegal.

4. Untuk mengetahui apakah reputasi pendidik berpengaruh secara parsial terhadap keputusan mahasiswa dalam memilih program studi sarjana terapan akuntansi sektor publik pada Politeknik Harapan Bersama Tegal.
5. Untuk mengetahui apakah akreditasi prodi, motivasi, fasilitas pendidikan dan reputasi pendidik berpengaruh secara simultan terhadap keputusan mahasiswa dalam memilih program studi sarjana terapan akuntansi sektor publik pada Politeknik Harapan Bersama Tegal.

\section{TINJAUAN PUSTAKA}

\section{Akreditasi Program Studi}

Akreditasi merupakan pengakuan terhadap perguruan tinggi atau program studi yang menunjukkan bahwa perguruan tinggi atau program studi tersebut dalam melaksanakan program pendidikan dan mutu lulusan yang dihasilkannya, telah memenuhi standar yan ditetapkan oleh Badan Akreditasi Nasional Perguruan Tinggi (BAN-PT). Hal ini menunjukkan bahwa perguruan tinggi yang sudah terakreditasi mendapat pengakuan yang lebih besar di masyarakat dibandingkan dengan perguruan tinggi yang belum terakreditasi Prasetyo, 2014 dalam verawati (2016). Penelitian

\section{Motivasi}

Menurut Mutia dan Evi, 2012 dalam verawati (2016) "Motivasi adalah pemberian daya penggerak yang menciptakan kegiatan kerja seseorang, agar mereka mau bekerja sama, bekerja efektif dan terintegrasi dengan segala daya upayanya untuk mencapai kepuasan". Motivasi adalah mengerjakan sesuatu lebih dari apa yang seharusnya dikerjakan. Seperti itulah pengertian yang berlaku yang sering kita dengar.

\section{Fasilitas Pendidikan}

Dalam usaha yang bergerak dibidang jasa, maka segala fasilitas yang ada yaitu kondisi fasilitas, kelengkapan, desain interior, dan kebersihan fasilitas harus diperhatikan terutama yang berkaitan erat dengan apa yang dirasakan atau didapat konsumen secara langsung. Fasilitas sendiri merupakan sumber daya fisik yang harus ada sebelum suatu jasa dapat ditawarkan kepada konsumen. Fasilitas yang disediakan oleh perusahaan jasa sangat mempengaruhi keputusan konsumen, karena erat kaitannya dengan pembentukan persepsi pelanggan. Keeratan hubungan tersebut dapat dilihat dari kecenderungan yang tampak pada pasar produk sekarang ini, dimana konsumen memiliki keinginan agar produk memiliki 
fasilitas yang lengkap (Sutiono, 2000 dalam verawati, 2016).

\section{Reputasi Pendidik}

Reputasi diatrikan sebagi nama baik. Nama baik tersebut bukan kita yang menyematkan, namun orang lain yang memberikan penilaian kepada kita. Dengan kata lain, reputasi kita atau seseorang baik bukan kita sendiri yang menilai tetapi orang lain yang menilai setelah melihat perbuatan kita. Pendidik adalah orang yang telah memanggul tanggung jawab sebagai salah satu pembentuk karakter peserta didik. Sumbangan karakter Pendidik termasuk yang paling kontributif. Karena pengaruh seorang Pendidik terhadap anak didiknya hampir sebesar pengaruh orang tua terhadap anaknya. Peribahas menyebutkan "Pendidik kencing berdiri, maka murid kencing berlari" ungkapan yang sudah tidak asing bagi kita semua. Makna dari pribahasa ini menunjukkan bahwa Pendidik mengajarkan karakter baik maka

Pendidik juga harus mengikuti apa yang ia sampaikan (Verawati, 2016).

\section{Teori Pemasaran}

Secara teoritik penelitian ini didasari teori tentang perguruan tinggi, pemasaran jasa pendidikan serta faktor-faktor yang mempengaruhi pemasaran. Perguruan tinggi adalah organisasi yang bergerak dalam usaha pendidikan yang menghasilkan produk yang berupa jasa pendidikan dan harus dipasarkan kepada konsumen (mahasiswa) Bartos (dalam Pakpahan, 2013). Perguruan tinggi mempunyai pengertian pendidikan pada jenjang yang lebih tinggi dari pada pendidikan menengah di jalur pendidikan sekolah. "Jenis-jenis perguruan tinggi dapat berbentuk universitas, institut, sekolah tinggi, akademi dan politeknik" (Sugiyono, 2004).

Pemasaran adalah suatu fungsi organisasi dan seperangkat proses untuk menciptakan, mengomunikasikan, dan menyerahkan nilai kepada pelanggan dan mengelola hubungan pelanggan dengan cara yang menguntungkan organisasi dan para pemilik sahamnya" Kotler (2008). Menurut Muliadi (2011) mengatakan bahwa lembaga pendidikan adalah sebuah lembaga yang bergerak dibidang layanan jasa pendidikan yang kegiatannya melayani konsumen berupa murid, siswa, mahasiswa dan masyarakat umum. Pemasaran untuk lembaga pendidikan (terutama sekolah) mutlak diperlukan. Pertama, sebagai lembaga non profit yang bergerak dalambidang jasa pendidikan, perlu meyakinkan masyarakat dan "pelanggan" (peserta didik, orang tua, serta pihak-pihak terkait lainnya) bahwa lembaga pendidikan yang dikelola masih tetap eksis. Kedua, meyakinkan masyarakat dan "pelanggan" bahwa layanan jasa pendidikan yang dilakukan sungguh relevan dengan kebutuhan mereka. Ketiga, perlu melakukan kegiatan pemasaran agar jenis dan macam jasa pendidikan yang dilakukan dapat dikenal dan dimengerti secara luas oleh masyarakat. Keempat, agar eksistensi lembaga pendidikan yang dikelola tidak ditinggalkan oleh masyarakat luas serta "pelanggan" potensial. Menurut John R. Silber (dalam Buchari, 2009) menyatakan bahwa etika marketing dalam dunia pendidikan adalah menawarkan mutu layanan intelektual dan membentuk watak secara menyeluruh. Dengan demikian, kegiatan pemasaran bukan sekedar kegiatan bisnis agar lembaga-lembaga pendidikan yang dikelola mendapatkan peserta didik atau murid, melainkan juga merupakan bentuk tanggung jawab (accountability) lembaga pendidikan kepada masyarakat luas.

Dengan demikian, kegiatan pemasaran bukan sekedar kegiatan bisnis agar lembagalembaga pendidikan yang dikelola mendapatkan peserta didik atau murid, melainkan juga merupakan bentuk tanggung jawab (accountability) lembaga pendidikan kepada masyarakat luas. Penentuan strategi pemasaran harus didasarkan atas analisa lingkungan eksternal dan internal organisasi (Wijaya, 2008).

\section{PENELITIAN TERDAHULU}

Penelitian Verawati (2016) Berdasarkan hasil analisis data dapat disimpulkan bahwa faktor-faktor yang mempengaruhi minat mahasiswa untuk melanjutkan Magister Akuntansi meliputi motivasi, akreditasi program studi, fasilitas pendidikan, konsentrasi jurusan, biaya pendidikan, dan reputasi pendidik. Sehingga dapat diartikan bahwa keenam variabel independen tersebut berpengaruh signifikan terhadap minat mahasiswa untuk melanjutkan Magister Akuntansi, hal ini ditunjukkan oleh nilai $\mathrm{p}$ value masing-masing variabel $<0,05$. Sehingga hipotesis H1 sampai H6 dapat diterima kebenarannya.

Menurut Rahmadiane dan Kamal, (2017) dalam penelitian yang berjudul Pengaruh 
Persepsi, Akreditasi Prodi, Dan Promosi Terhadap Keputusan Memilih Program Studi Akuntansi Pada Politeknik Harapan Bersama bahwa hasil penelitian menunjukkan bahwa persepsi mahasiswa, akreditasi prodi, dan promosi berpengaruh terhadap keputusan mahasiswa memilih program studi Akuntansi pada Politeknik Harapan Bersama dan akreditasi prodi merupakan variabel yang paling berpengaruh terhadap keputusan mahasiswa memilih program studi Akuntansi pada Politeknik Harapan Bersama.

\section{HIPOTESIS}

Hipotesis dalam Penelitian ini adalah

H1: Akreditasi Prodi berpengaruh secara parsial terhadap keputusan mahasiswa dalam memilih program studi sarjana terapan akuntansi sektor publik pada Politeknik Harapan Bersama Tegal.

H2: Motivasi berpengaruh secara parsial terhadap keputusan mahasiswa dalam memilih program studi sarjana terapan akuntansi sektor publik pada Politeknik Harapan Bersama Tegal.

H3: Fasilitas Pendidikan berpengaruh secara parsial terhadap keputusan mahasiswa dalam memilih program studi sarjana terapan akuntansi sektor publik pada Politeknik Harapan Bersama Tegal.

H4: Reputasi Pendidik berpengaruh secara parsial terhadap keputusan mahasiswa dalam memilih program studi sarjana terapan akuntansi sektor publik pada Politeknik Harapan Bersama Tegal.

H5: Akreditasi prodi, motivasi, fasilitas pendidikan dan reputasi pendidik berpengaruh secara simultan terhadap keputusan mahasiswa dalam memilih program studi sarjana terapan akuntansi sektor publik pada Politeknik Harapan Bersama Tegal.

\section{METODE PENELITIAN}

Penelitian ini dilakukan di program studi sarjana terapan akuntansi sektor publik politeknik harapan bersama. Populasi dalam penelitian ini sebanyak 47 Orang Mahasiswa. Sedangkan teknik pengambilan Sampel dalam penelitian ini menggunakan Purposive Sampling. kriteria pengambilan sampel dalam penelitian ini diantarany Mahasiswa yang mendaftar dan registrasi serta mahasiswa aktif yang ada pada program studi sarjana terapan akuntansi sektor publik tahun akademik 2020/2020. Sehingga sample dalam penelitian ini sebanyak 44 orang mahasiswa.

Metode analisis data yang digunakan dalam penelitian ini diantaranya Uji Instrumen Data, Uji Asumsi Klasik, Uji Hipotesis dan Regresi Linear Berganda.

\section{HASIL DAN PEMBAHASAN}

\section{Hasil anlisis data}

\section{Uji Validitas dan Reliabilitas}

Dalam penelitian ini yang terdiri dari variabel akreditasi program studi (x1), motivasi (x2), fasilitas pendidikan (x3) dan reputasi pendidik $(\mathrm{x} 4)$ terhadap kepuasan memilih (Y) telah valid, hal ini karena nilai Sig. (2-tailed) $<0,005$. Dan reliabel karenan nilai Cronbach's Alpha seluruh variabel $\mathrm{x}$ maupun y bernilai lebih dari 0.60 .

\section{Uji Asumsi Klasik}

\section{a. Uji Normalitas}

berdasarkan hasil analisis diatas bahwa nilai Asymp. Sig. (2-tailed) > 0.005. hal ini berarti nilai residual terstandarisasi dinyatakan menyebar secara normal.

\section{b. Uji Multikolinearitas}

Berdasarkan hasil analisis diatas bahwa VIF (Variance Infloating Factor) variabel akreditasi program studi, motivasi, fasilitas pendidikan dan reputasi pendidik lebih kecil dari 10 , maka model regresi yang terbentuk tidak terjadi gelaja multikolinearitas.

\section{c. Uji Heterokedastisitas}

Berdasarkan hasil analisis diatas bahwa model regresi tidak terjadi gelaja heterokedastisitas, hal ini karena Sig. variabel akreditasi program studi, motivasi, fasilitas pendidikan dan reputasi pendidik lebih besar dari 0,005.

\section{d. Uji Autokorelasi}

Berdasarkan hasil analisis diatas bahwa diperoleh nilai Asymp. Sig. (2-tailed) sebesar $0,170>0.005$. dengan demikian maka tidak terjadi gejala autokorelasi.

\section{Uji Hipotesis}
a. Uji t 
Berdasarkan hasil analisis diatas untuk uji hipotesis uji t maka:

1. Variabel akreditasi program studi (X1) nilai sig. > 0,05 hal ini bahwa variabel akreditasi program studi tidak berpengaruh terhadap keputusan mahasiswa dalam memilih program studi sarjana terapan akuntansi sektor publik.

2. Variabel motivasi (X2) nilai sig. > 0,05 hal ini bahwa variabel motivasi tidak berpengaruh terhadap keputusan mahasiswa dalam memilih program studi sarjana terapan akuntansi sektor publik.

3. Variabel fasilitas pendidikan (X3) nilai sig. > 0,05 hal ini bahwa variabel fasilitas pendidikan tidak berpengaruh terhadap keputusan mahasiswa dalam memilih program studi sarjana terapan akuntansi sektor publik.

4. Variabel reputasi pendidik (X4) nilai sig. $<0,05$ hal ini bahwa variabel reputasi pendidik berpengaruh terhadap keputusan mahasiswa dalam memilih program studi sarjana terapan akuntansi sektor publik.

\section{b. Uji F}

Berdasarkan hasil analisis diatas nilai sig. lebih kecil dari nilai probabilitas 0,05 berarti secara bersama-sama (simultan) akreditasi prodi, motivasi, fasilitas pendidikan dan reputasi pendidik berpengaruh terhadap keputusan mahasiswa dalam memilih program studi sarjana terapan akuntansi sektor publik.

\section{Koefisien Determinasi $\mathbf{R}^{2}$}

Berdasarkan hasil analisis diatas dapat disimpulkan bahwa akreditasi prodi, motivasi, fasilitas pendidikan dan reputasi pendidik berpengaruh sebesar $38,9 \%$ terhadap keputusan mahasiswa dalam memilih program studi sarjana terapan akuntansi sektor publik., sedangkan $61,10 \%$ dipengaruhi variabel lain yang tidak diteliti. Karena nilai R Square dibawah 5\% atau cenderung mendekati nilai 0 maka dapat disimpulkan kemampuan variabel-variabel independen dalam menjelaskan variasi variabel amat terbatas.

\section{PEMBAHASAN}

1. Pengaruh Akreditasi Prodi Secara Parsial Terhadap Keputusan Mahasiswa Dalam Memilih Program Studi Sarjana Terapan Akuntansi Sektor Publik Pada Politeknik Harapan Bersama Tegal.

Berdasarkan hasil analisis yang telah dilakukan bahwa variabel akreditasi program studi secara parsial tidak berpengaruh terhadap keputusan memilih program studi sarjana terapan akuntansi sektor publik politeknik harapan bersama, hal ini dikarenakan mahasiswa program studi sarjana terapan akuntansi sektor publik dalam memilih program studi tidak mementingkan status akreditasi prodi yang ada. penelitian ini sejalan dengan penelitian yang dilakukan oleh iriani, oktariana, dan lestari (2007) bahwa minat studi mahasiswa didelapan prodi di universitas widyatama tidak dipengaruhi oleh status akreditasi. Akan tetapi Penelitian ini tidak sejalan dengan penelitian yang dilakukan oleh Rahmadiane dan Kamal, (2017) dalam penelitian yang berjudul Pengaruh Persepsi, Akreditasi Prodi, Dan Promosi Terhadap Keputusan Memilih Program Studi Akuntansi Pada Politeknik Harapan Bersama bahwa hasil penelitian menunjukkan bahwa persepsi mahasiswa, akreditasi prodi, dan promosi berpengaruh terhadap keputusan mahasiswa memilih program studi Akuntansi pada Politeknik Harapan Bersama dan akreditasi prodi merupakan variabel yang paling berpengaruh terhadap keputusan mahasiswa memilih program studi Akuntansi pada Politeknik Harapan Bersama.

2. Pengaruh Motivasi Secara Parsial Terhadap Keputusan Mahasiswa Dalam Memilih Program Studi Sarjana Terapan Akuntansi Sektor Publik Pada Politeknik Harapan Bersama Tegal.

Berdasarkan hasil analisis yang telah dilakukan bahwa variabel motivasi secara parsial tidak berpengaruh terhadap keputusan memilih program studi sarjana terapan akuntansi sektor publik politeknik harapan bersama, hal ini dikarenakan mahasiswa tidak didorong oleh ada nya motivasi untuk memilih program studi, 
penelitian ini tidak sejalan dengan penelitian yang dilakukan oleh mahmuda, (2008) bahwa Minat mahasiswa untuk mengikuti PPA dipengaruhi oleh motivasi kualitas, motivasi karir, motivasi ekonomi, dan motivasi sosial. Faktor motivasi sosial memberikan kontribusi terbesar terhadap minat dibandingkan dengan faktor motivasi yang lainnya. Sementara itu, motivasi karir terbukti berpengaruh pada minat pada taraf signifikansi $10 \%$. Secara keseluruhan, dimensi motivasi memberikan kontribusi $23,2 \%$ terhadap minat.

3. Pengaruh Fasilitas Pendidikan Secara Parsial Terhadap Keputusan Mahasiswa Dalam Memilih Program Studi Sarjana Terapan Akuntansi Sektor Publik Pada Politeknik Harapan Bersama Tegal.

Berdasarkan hasil analisis yang telah dilakukan bahwa variabel fasilitas pendidikan secara parsial tidak berpengaruh terhadap keputusan memilih program studi sarjana terapan akuntansi sektor publik politeknik harapan bersama, hal ini dikarenakan mahasiswa memilik prodi sarjana terapan tidak melihat kelengkapan fasilitas pendidikan yang ada, penelitian ini tidak sejalan dengan penelitian yang dilakuakan oleh amaliya (2018) yang menyatakan bahwa Hasil penelitian menunjukkan bahwa: (1) Biaya pendidikan tidak berpengaruh terhadap keputusan mahasiswa dengan ditunjukkan oleh nilai thitung $=-0,199$ dengan sigifikansi 0,843 . (2) Citra prodi berpengaruh positif dan signifikan terhadap keputusan mahasiswa dengan ditunjukkan oleh nilai thitung = 2,799 dengan sigifikansi 0,036. (3) Fasilitas pendidikan berpengaruh positif dan signifikan terhadap keputusan mahasiswa dengan ditunjukkan oleh nilai thitung $=$ 2,957 dengan sigifikansi 0,011. (4) Prospek prodi berpengaruh positif dan signifikan terhadap keputusan mahasiswa dengan ditunjukkan oleh nilai thitung $=9,215$ dengan sigifikansi 0,000 . (5) Biaya pendidikan, citra prodi, fasilitas pendidikan, dan prospek prodi secara simultan berpengaruh positif dan signifikan terhadap keputusan mahasiswa dengan nilai Fhitung $=35,086$ dan signifikansi 0,000. Sumbangan efektif ke 4 variabel bebas sebesar 51,9\% dan sisanya $48,1 \%$ dipengaruhi oleh variabel lain. Adapun variabel yang paling dominan kontribusinya adalah variabel prospek prodi dengan $\mathrm{SE}=40,6 \%$ dan $\mathrm{SR}=78,2 \%$.

4. Pengaruh Reputasi Pendidik Secara Parsial Terhadap Keputusan Mahasiswa Dalam Memilih Program Studi Sarjana Terapan Akuntansi Sektor Publik Pada Politeknik Harapan Bersama Tegal.

Berdasarkan hasil analisis yang telah dilakukan bahwa variabel reputasi pendidik secara parsial berpengaruh terhadap keputusan memilih program studi sarjana terapan akuntansi sektor publik politeknik harapan bersama, hal ini dikarenakan mahasiswa melihat latar belakang pendidikan dosen serta kemampuan dosen dalam memberikan pengajaran, penelitian ini sejalan dengan penelitian yang dilakukan oleh verawati (2016) yang menyatakan bahwa Reputasi pendidik berpengaruh positif terhadap minat mahasiswa melanjutkan magister akuntansi, terbukti dari nilai thitung sebesar 3,297 > t tabel $(2,017)(\mathrm{p}=0,002<0,05)$.

5. Pengaruh Akreditasi Prodi, Motivasi, Fasilitas Pendidikan Dan Reputasi Pendidik Secara Simultan Terhadap Keputusan Mahasiswa Dalam Memilih Program Studi Sarjana Terapan Akuntansi Sektor Publik Pada Politeknik Harapan Bersama Tegal.

Berdasarkan hasil analisis yang telah dilakukan bahwa variabel Akreditasi Prodi, Motivasi, Fasilitas Pendidikan Dan Reputasi Pendidik secara simultan berpengaruh terhadap keputusan memilih program studi sarjana terapan akuntansi sektor publik politeknik harapan bersama hal ini sejalan dengan penelitian yang dilakukan oleh verawati (2016) yang menyatakan bahwa Berdasarkan hasil analisis data dapat disimpulkan bahwa faktor-faktor yang mempengaruhi minat mahasiswa untuk melanjutkan Magister Akuntansi meliputi motivasi, akreditasi program studi, fasilitas pendidikan, konsentrasi jurusan, biaya pendidikan, dan reputasi pendidik. Sehingga dapat diartikan bahwa keenam variabel independen tersebut berpengaruh signifikan terhadap minat mahasiswa untuk melanjutkan Magister Akuntansi, hal ini ditunjukkan oleh nilai $\mathrm{p}$ value masing- 
masing variabel $<0,05$. Sehingga hipotesis H1 sampai H6 dapat diterima kebenarannya.

\section{KESIMPULAN}

Berdasarkan hasil analisis data yang telah dilakukan maka dapat disimpulkan bahwa Variabel akreditasi program studi (X1) nilai sig. $>0,05$ hal ini bahwa variabel akreditasi program studi tidak berpengaruh terhadap keputusan mahasiswa dalam memilih program studi sarjana terapan akuntansi sektor publik. Variabel motivasi (X2) nilai sig. > 0,05 hal ini bahwa variabel motivasi tidak berpengaruh terhadap keputusan mahasiswa dalam memilih program studi sarjana terapan akuntansi sektor publik. Variabel fasilitas pendidikan (X3) nilai sig. > 0,05 hal ini bahwa variabel fasilitas pendidikan tidak berpengaruh terhadap keputusan mahasiswa dalam memilih program studi sarjana terapan akuntansi sektor publik. Variabel reputasi pendidik (X4) nilai sig. $<0,05$ hal ini bahwa variabel reputasi pendidik berpengaruh terhadap keputusan mahasiswa dalam memilih program studi sarjana terapan akuntansi sektor publik. Sedangkan secara simultan variabel Akreditasi Prodi, Motivasi, Fasilitas Pendidikan Dan Reputasi Pendidik berpengaruh terhadap keputusan mahasiswa dalam memilih program studi sarjana terapan akuntansi sektor publik, hal ini karena nilai sig $<0,05$.

Nilai R2 yang disesuaikan (adjusted $R$ square) yang menyatakan tingkat kontribusi antara variabel dependen dan independen yaitu $5 \%$ hal ini nilai yang diperoleh sangat kecil, berarti masih ada variabel bebas lain yang mempengaruhi keputusan memilih program studi sarjana terapan akuntansi sektor publik.

\section{KETERBATASAN}

Keterbatasan yang ada dalam penelitian ini yaitu waktu dalam penyebaran kuesioner kepada mahasiswa karena harus menyesuaikan jadwal pengajaran mahasiswa sebagai responden dan kurang nya memasukan variabel-variabel yang dimungkinkan berpengaruh terhadap keputusan memilih program studi sarjana terapan akuntansi sektor publik politeknik harapan bersama.

\section{DAFTAR PUSTAKA}

Aini, Yulfita. 2010. Analisis Pengaruh Marketing Mix Terhadap Keputusan Mahasiswa dalam Melanjutkan Studi pada Perguruan Tinggi.

Universitas Pasir Pengaraian.

Bawantara, Agung. 2007. Lulus SMA Kuliah Dimana? Panduan Memilih Program Studi. PT. Kawan Pustaka. Jakarta.

Amaliya, Rizqi. 2018. Faktor-Faktor Yang Mempengaruhi Keputusan Mahasiswa Dalam Menempuh Pendidikan Padaprogram Studi Pendidikan Ekonomi $\mathrm{Fe}$ UNY. SKRIPSI. Program Studi Pendidikan Ekonomifakultas Ekonomiuniversitas Negeri Yogyakarta.

Verawati, Dita. 2016. Pengaruh Motivasi, Akreditasi Prodi, Fasilitas Pendidikan, Konsentrasi Jurusan, Biaya Pendidikan Dan Reputasi Pendidik Terhadap Minat Mahasiswa Untuk Melanjutkan Magister Akuntansi (Studi Empiris Pada Mahasiswa Akuntansi Di Ums). Skripsi. Progam Studi Akuntansi fakultas Ekonomi Dan Bisnis universitas Muhammadiyah Surakarta.

Pakpahan, Efendi. 2013. Pengertian, Tugas dan Fungsi Perguruan Tinggi.http://tugasakhiramik.blogspot.c om/2013/07/pengertian-tugas-dan fungsi-perguruan.html. (diakses tanggal 8 Oktober 2020).

Sugiyono. 2004. Manajemen Pendidikan Tinggi. Cetakan Pertama. PT. Aneka Cipta. Jakarta

Kotler, Philip., Keller, 2008. Ali Bahasa: Benyamin Molan. Penyunting: Bambang Sarwaji. Manajemen Pemasaran. edisi 12 Jilid 2. PT. INDEK. Jakarta.

Muliadi, Erlan. 2011. Pemasaran Pendidikan. Tersedia pada http://erlanmuliadi.blogspot.com/2011/0 6/pemasaran-pendidikan.html. (diakses tanggal 8 Oktober 2020).

Buchari, Alma. 2009. Manajemen Pemasaran dan Pemasaran Jasa. CV Alfabeta. Bandung.

Wijaya, David. 2008. Pemasaran Jasa Pendidikan. Tersedia Pada www.bpkpenabur.or.id/files/hal.4256PemasaranPendidikan.pdf. (diakses tanggal 8 Oktober 2020).

\section{UCAPAN TERIMA KASIH}

Penulis mengucapkan terima kasih yang sebesar-besarnya kepada seluruh pihak yang telah membantu dan mendukung terlaksananya kegiatan penelitian ini. Secara khusus, ucapan terima kasih diberikan kepada pihak mahasiswa 
dan mahasiswi program studi sarjana terapan akuntansi sektor publik yang telah menerima dan bersedia bekerjasama dengan penulis. 